\title{
PARTY LEADERSHIP SELECTION IN THE UNITED KINGDOM
}

by BRUNO MARINO and STEFANO ROMBI

Quaderni dell'Osservatorio elettorale n .78, dicembre 2017, pp. 69-91 
Abstract. - In the past few decades, British parties have undergone deep transformations, also concerning their leader selection rules. It could be interesting to directly tackle this area of intra-party changes, also given the increasing attention devoted to party leaders and to their mode of selection. This article will explore both the precise features of the changes in the rules governing the selection of party leaders (particularly focusing on the selectorate), and also the characteristics of most recent leadership races occurred in the most important parties in the United Kingdom. To begin with, the article will explore the expansions of the selectorate occurred between the mid-1960s and today, particularly analysing the implementation of OMOV(one-member one-vote) systems. Second, attention will be devoted to the precise features of the selection mechanisms, by applying the quadripartite scheme devised by Hazan and Rahat (the selectorate, the candidacy, the decentralization, and the voting system). Third, we will focus on the most recent leadership races that elected Jeremy Corbyn and Theresa May asleader of, respectively, the Labour and the Conservative Party. All in all, the article shows that British parties have surely undergone deep transformations concerning the rules for the selection of their leaders and the precise features of recent leadership races, but also that a full empowerment of party members has not been reached yet.

Keywords: Leadership selection, Parties, United Kingdom, Labour, Conservative 


\section{Introduction}

The United Kingdom has often been considered a country where abrupt change and revolution are not welcome. From an institutional viewpoint, after the devastating English Civil War in the mid- $17^{\text {th }}$ century, only slow, bloodless, and incremental reforms have appeared to take place. Although this is more a myth than historical reality, there is one area where only cautious changes have taken place: party leadership selection. Indeed, the most important British parties have gradually opened the rules to select their leaders (empowering a wider set of people than before), with a progressive evolution. Analysing the party leadership selection in British parties can give us a precise and in-depth picture of what has occurred in the UK's most important political formations from both a historical and a contemporary viewpoint. More specifically, it is widely known that party leaders have become increasingly important from several perspectives (see for instance Poguntke and Webb 2005; Curtice and Lisi 2015; Musella 2018). It is also through their leaders that political parties engage in combat in several arenas of competition. British political parties make an interesting case study for several reasons: not only did they implement leader selection procedures empowering party members quite early compared to other Western European countries, but they have also opened their leader selection rules a noticeable number of times. Moreover, new, more open rules for leader selection have been implemented in the leadership races that will be analysed in this article. Finally, studying leadership selection rules and their evolution over time is interesting for a series of reasons. Indeed, there may be a connection between more open leader selection rules and, for example, participation in leader selection races (e.g., see Wauters 2015) or party members' views on intra-party matters (Bernardi, Sandri and Seddone 2017). Therefore, shedding light on party leader selection in the UK can be attractive from several viewpoints.

This study analyses party leadership selection rules and leadership races in the main British political parties. Section 2 will address the historical account of openings in leadership selection rules in the Liberal Party (Liberal Democrats), the Conservatives, and the Labour party from the mid-1960s until today. These three parties have been chosen not only because they are important actors in the British political system but also because they have implemented - in different fashions and at different moments - openings in their leader selection rules that are worthy of investigation. Section 2 will specifically focus on the «selectorate» (the body of people with the power to select an organ) (Rahat and Hazan 2001) and will describe the reforms by the three abovementioned parties 
concerning the party leader selectorate in depth, a body that has evolved from being composed of MPs only in the 1960s to including either totally (for the Liberal Democrats and the Labour Party) or partially (for the Conservative Party) members of each political formation. Section 2 will also focus on the increasing empowerment of party members, or the progressive movement by British parties towards the OMOV ("one-member, one-vote") system, although this evolution has been neither linear nor complete for all political formations. Section 2 will also take into account some crucial aspects of these reforms: their incremental and gradual nature; the continuing power of Members of Parliament in the process of leadership selection; and the different causes connected to the changes of the selectorate.

After describing this historical evolution, Section 3 will tackle the current rules in the Conservative Party and the Labour Party for selecting a leader. More specifically, attention will be devoted to four specific dimensions of analysis: the already-encountered selectorate, the «candidacy» (the possible requisites and characteristics of candidates for party leadership), the «de-selection mechanisms» (i.e., the manner the leader is held accountable by his/her party), and, finally, the voting system (i.e., the precise way in which the party leader is selected) (Kenig 2009). The analysis of these four dimensions can give us an in-depth picture of the features of the leadership selection in the two abovementioned British parties. The selectorate shows some interesting differences: Conservative MPs have a first say in the selection of the two candidates who will fight for Conservative members' support in a run-off ballot, whereas Labour MPs do not have such power. Conversely, the latter party members are more important in the candidacy dimension given that a prospective Labour party leader must secure the support of a noticeable percentage of party's MPs and MEPs, whereas a person willing to stand as a candidate for the Conservative party leadership needs the support of a remarkably lower number of parliamentarians. Finally, even from the voting system viewpoint, there are some interesting differences between the two parties.

Section 4 will account for the outcomes of the most recent party leadership selection races in the Conservative and the Labour Party, both held in 2016. An account of these two leadership elections will shed light on the dynamics of internal competition within the two major British parties. In particular, the analysis should help us understand whether and how the leadership selection rules worked during a critical moment for both the Labour and the Conservative parties. Although in a different form, in 2016, both parties were going through a resettlement phase: the Labour party 
faced the challenge of a large part of the (parliamentary) party against the leader, Jeremy Corbyn, elected only a year earlier, whereas the Tories faced the negative organisational consequences of David Cameron's defeat in the Brexit Referendum. It was precisely this referendum that had profound effects not only on British politics at large but on British parties and party leaders as well. Indeed, after the Brexit referendum, David Cameron, leader of the Conservatives, resigned, and this triggered the selection process that ended with the possibly unexpected victory of Theresa May, who became Prime Minister in 2016. Even on the Labour party side, severe criticism of Jeremy Corbyn triggered the leadership selection process, which ended with a robust and unquestionable victory of the incumbent party leader.

Finally, Section 5 will present our conclusions.

\section{Party Leadership Selection in the UK - a Longitudinal Prospective}

Turning our attention to specific parties and time periods, it is necessary to clarify our object of study. We will mainly focus on the selectorate, which is the body of people that selects an organ - in this case, the party leader (Rahat and Hazan 2001; Bueno De Mesquita et al. 2002). This dimension can be operationalised in a very peculiar way. Following Kenig, Rahat and Hazan (2015), the various bodies of people selecting the party leader can be positioned on an inclusiveness/exclusiveness continuum, which ranges from party voters, to party members, passing to the party congress, the parliamentary party group, a party elite, and, finally, to a leader him/herself. A first add-on is necessary: specific attention will be devoted to the implementation of 'one-member, one-vote' (OMOV) systems to select the party leader. In other words, the focus will not simply be on the general empowerment of party members but also on the fact that each member receives (or not) an equal say in the party leader selection. A second small addendum is as follows: the Labour Party, for a given period, selected its leader via a selectorate made up on different bodies of people. Following Hazan and Rahat 2010 (37-38) and Kenig et al. (2015, p. 6), we must add the electoral college to the inclusiveness/exclusiveness continuum we have just defined. We will explain in a moment its extremely interesting features.

Let us now turn our attention to the specific rules governing the selectorates for British party leaders from mid-1960s to the mid-2010s, following the period on which Pilet and Cross (2014) focus their attention. As argued in the introduction, we will discuss three parties: the Liberal Democrats (and its predecessors), the Labour Party and the Conservative Party. 
From 1965 until 1975, all the main British parties (the then-existing Liberal Party and the Conservatives and the Labour Party) selected the party leader via their Members of Parliament (Bale and Webb 2014; Denham and Dorey 2017). This is not surprising given the powerful role that the Parliament has had in Britain's national history. However, in 1976, a first relevant opening occurred: in the Liberal Party, party members were allowed to select the party leader. This was not an OMOV system; as explained by Punnett (1993), a complex procedure allocating vote quotas based on the number of party members and the percentage of votes obtained by the party in each constituency was put forward. Thus, whereas on the one hand, this procedure is different from that implemented to select the leader of the British Labour Party itself from 2014 onwards (see below and also Section 3), on the other hand, the 1976 decision by the Liberal Party marked a strong discontinuity with the existing rules to select the party leader both in the United Kingdom and abroad. Indeed, in the mid-1970s, only a handful of parties allowed their members to select their leader (for instance, the Belgian Christian Social Party, the current Humanist Democratic Centre; see Pilet and Wauters 2014). Hence, the decision made by the Liberal Party's elites was an innovative one, albeit lacking in the OMOV procedure.

In the 1980s, the first party in the United Kingdom to adopt the OMOV system was the Social Democratic Party (SDP). This party originated from a split from the Labour Party, and in 1982, there was a decision - curiously, made by party members themselves - according to which the selectorate for the party leader would be made up of party members who would select the head of the party via a direct vote (Punnett 1993; Denham 2017). Note that this cannot be considered an opening per se given that there were no previous rules for selecting an SDP party leader. Nonetheless, it was a significant decision, not only because the OMOV procedure entered British politics but also because in 1988, the SDP and the Liberal Party merged to form the Liberal Democrats, and it was the SDP procedure and its selectorate for party leader that was adopted in the new political formation (Bale and Webb 2014).

In the 1980s, a third change was put forward, this time within the Labour Party. Up to that year, the leader of the party was selected by its MPs; however, in 1981, a peculiar selectorate was put in place: the electoral college. Three different selectorates formed this college: the affiliated societies (mainly, but not exclusively, the trade unions, with a share of the final votes equal to $40 \%$ ), the party MPs (with $30 \%$ of the final votes), and the party members (even in this case, they received $30 \%$ of the final votes of the college) (Punnett 1993; Bale and Webb 2014). As noted by Bale and 
Webb (2014, p. 14), «Delegates from the various affiliated unions, societies and CLPs always cast their votes as monolithic "blocks" and were often mandated to vote in a certain way by the bodies they represented». Even in this case, the well-known historical link between the Labour Party and the trade unions contributes to explaining why such a peculiar selectorate was put in place (see, for instance, the discussion in Webb and Bale 2017). Nonetheless, another interesting element is worth examining: party members did not receive full power to select the party leader. Their vote share was balanced with that of affiliated societies and party MPs.

Turning to the 1990s, in 1992, a small reform in the Labour Party allowed Members of the European Parliament to be included in the MPrelated section of the party leader electoral college (Bale and Webb 2014), and in 1993, the Labour Party underwent another reform. In that year, the share of votes attributed to each of the three selectorates was modified (giving an equal share of the final votes to each of the three bodies), and the voting system for the final selection of the leader was changed (introducing a college-related OMOV in the sense that delegates from each of the three components of electoral college would have individually voted in the subsequent party leadership elections) (Bale and Webb 2014). This opening, although rarely discussed, undoubtedly represents a small movement towards the implementation of the OMOV system, which was at least applied to all people comprising the Labour Party leader's electoral college. Nonetheless, the most important change in British parties' leader selection rules of the 1990s is surely the 1998 reform that occurred in the Conservative Party, when a two-phase selection process was put in place. Specifically, if there are more than two candidates, a first 'elimination' phase is performed by party MPs, who reduce, in successive rounds of voting, the number of candidates for party leadership to two people. Then, the party leader is selected between these two people by the party members in an OMOV procedure (Denham 2010; Bale and Webb 2014). It is unsurprising that party members are given substantial power in selecting the party leader (in that it is their direct and equal vote to choose the upcoming party leader), but it should be noted that a strong influence is retained by party MPs, who can remove an unwelcome candidate from the party leadership race in the preliminary ballots.

Until 2014, two of the three main British parties (the Liberal Democrats and the Conservative Party) allowed their members to select the party leader with an OMOV procedure, notwithstanding the abovementioned limitations. Only the Labour Party lacked such an inclusive procedure, but this situation changed in 2014. In that year, a report put 
forward a series of proposals for the Labour Party, including the recommendation to switch to an OMOV system to select the party leader (Collins 2014). A subsequent party conference adopted this recommendation. Therefore, the leader of the Labour Party, from 2014 onwards, has been directly selected by party members. Interestingly, other changes that were proposed concern the power of affiliated societies' members: «affiliated supporters» (mostly trade union members) and ""registered supporters" [...] could register to vote in any future leadership contest, having declared their support for Labour's "aim and values" and paid a modest fee of three pounds» (Denham and Dorey 2017, p. 18). It can be safely argued that these decisions empowered Labour Party members at the expense of the organised affiliated societies (especially the trade unions). However, it could be said that giving the power to select the leader to «supporters», along with party members, might reduce members' leverage in that it enlarges the selectorate so much that supporters have the same selection power as party members (see also a compatible discussion on party activists' power balanced by that of party members in Katz and Mair, 2002).

What considerations should we take away from this account of the evolution of the three British parties' selectorate rules? A general trend towards the greater inclusion of party members in the selection of party leaders can be detected. Indeed, recalling the inclusiveness/exclusiveness continuum presented at the beginning of this section, all British parties fell on the MPs position in 1965 and are now located on the party members position. As argued, this does not mean that party members have absolute power concerning the selection of the party leader. Although their role has not diminished, especially if one compares the rules to select the British party leaders with those concerning the selection of other party leaders in other Western European countries (e.g., for Germany, see Detterbeck and Rohlfing 2014; for Norway, see Allern and Kalsen 2014; for Portugal, see Lisi and Freire 2014), we should not forget that party elites - especially party MPs - still retain a certain amount of power in party leader selection in the UK.

More specifically, let us briefly consider the issue related to the candidacy dimension, which is related to the features of the person who can stand as a candidate and, more crucially for this contribution, to the possible presence of specific requirements (e.g., the support of a certain number of party members) (Rahat and Hazan 2001; Kenig, Rahat and Hazan 2015). If we consider the candidacy dimension for British party leaders' selection, we can note that party MPs have a noticeable role to play. Indeed, party MPs' 
support - in various fashions, according to the party and the specific time period - is always a crucial element that prospective candidates must secure to appear before the selectorate (Punnett 1992; Cross and Blais 2012; Denham 2017). Moreover, the rules to select the party leader for the main British political formations require a prospective candidate to be an MP (see subsequent sections for more details); this is a further element to consider in weighting the influence of party MPs in leadership selection. This also means that the power of party members - albeit substantial and increasing over time - should be seen in connection with the abovementioned powers of party MPs.

A second important point concerns the scope and the width of changes in party leadership selectorates. The path towards the OMOV selection of party leaders has been long and slow. The SDP and the Liberal Democrats are the only parties that have directly implemented an OMOV system, which could be related to the fact that in the first case, the party established such a rule upon its formation, and in the second case, the existence of the OMOV itself in one of the two predecessor parties (the SDP) might have paved the way for the adoption of this system in the newly formed Liberal Democrat party. Moreover, whereas the Labour Party eventually switched to an OMOV system in 2014, the Conservatives did so in 1998, even if we consider the extremely powerful role of party MPs in selecting the two candidates for the run-off selection by the party members.

Another interesting point is related to the possible reasons behind the abovementioned changes in the selectorate. This is a long-debated issue. Some authors have connected such changes to the necessity of renewing the image of the party or to factional struggles for power (Punnett 1992), possibly related to more ideological clashes between party elites and the lower strata of the party (Punnett 1992), or between the parliamentary and the extra-parliamentary branches (Denham 2017). Conversely, others have focused on rank-and-file pressures to have a greater say in the leader selection process (Denham 2010) or, following the framework proposed by Barnea and Rahat on candidate selection (2007), on the effect of electoral defeats and a party's opposition status (see also Cross and Blais 2012). Although it is not possible to empirically verify all of these proposed explanations, let us focus on two factors, electoral defeats and the opposition status, following the descriptive analysis by Cross and Blais (2012). Concerning the latter, all the openings considered in this section occurred when the related party was in opposition (i.e., the Liberal Party in 1976, the Labour Party in 1981, and the Conservative Party in 1998). Turning to the former, with the possible exception of the 1993 Labour Party 
reform (which occurred after the 1992 general election, when the party obtained more seats and votes than the 1987 election despite remaining in opposition), all the instances of selectorate expansion occurred after an electoral defeat. This is an expansion of the descriptive analysis put forward by Cross and Blais (2012) in their analysis of the openings of the selectorate in the most important parties in the United Kingdom, Ireland, New Zealand, Australia, and Canada and obviously does not prove that there is a causal relationship between the alleged determinants and the openings. It simply suggests that more research is needed to precisely address the scope and importance of these factors in explaining the openings in party leader selection rules.

Thus far, we have presented a historical account of the party leader selection rules, specifically of the selectorate, for British party leaders between the mid-1960s and mid-2010s. At this point, we will turn to the analysis of the recent party leadership races in the United Kingdom, below and in subsequent sections.

\section{The rules of the 2016 Labour and Conservative party leadership contests}

In 2016, the two most important British political parties renewed their leadership. This section focuses on the rules overseeing the (re)selection of Jeremy Corbyn as the leader of the Labour Party and of Theresa May as the Conservative Party's leader in 2016.

As anticipated (see Section 2), on the basis of the suggestions of the Collins Report (2014), from 2014, the Labour switched to an OMOV system to select its leader. Approximately a year later, following the resignation of Ed Miliband due to Labour's defeat in the 2015 UK general election, the new selection mechanism was applied. Using a procedure that began on 9 June 2015 and ended on 12 September 2015, the Labour Party allowed members and supporters to select the new leader. The deputy Jeremy Corbyn obtained a landslide victory (Dorey and Denham 2016). There were several criticisms of his approach to the Remain campaign during the Brexit referendum, however, that led members to question Corbyn's leadership. First, more than half of the shadow cabinet resigned a few days after the victory of the Leave campaign; second, Corbyn suffered a vote of no confidence by the Parliamentary Labour Party (PLP): only 40 PLP members out of 212 supported Corbyn. These circumstances led the Labour Party to its second leadership selection in a year, which occurred from 12 June 2016 to 24 September 2016.

To understand the rules of the last Labour Party leadership selection, it may be useful to refer to the four analytical dimensions first presented by 
Kenig (2009): the selectorate (which selects the leader); the candidacy (who can put forward his/her candidacy as a party leader); the voting system (the way the party leader is specifically selected); and the de-selection mechanism (how the party regulates a leader's dethroning).

As for the candidacy, it is worth highlighting that only Members of Parliament can stand as candidates in the Labour Party. Rules stipulate that anyone who wants to challenge the sitting Labour leader needs the support of 20\% of Labour MPs and Members of the European Parliament (MEPs). After a heated discussion followed by a vote on 12 June 2016, the National Executive Committee (NEC) decided that the incumbent leader could automatically participate in the competition. Of course, this problem did not exist in 2015, when the incumbent leader, Ed Miliband, decided not to seek re-election.

The selectorate for the Labour Party leader included party members, registered supporters, and affiliated supporters. The Procedural Guidelines state that to participate as party members, citizens had to join the Labour Party on or before 12 June 2016. Contrarily to the Guidelines, however, the NEC decided that people who had been party members for less than six months could not vote. Moreover, to be entitled to vote, party members had to pay their arrears in full by 8 August 2016. By the same date, the Labour Party had to receive the new and updated affiliated supporters' lists. The final date to join as registered supporters was 20 July 2016. Although no additional explanations are needed for party members, we must provide some clarification regarding registered supporters and affiliated supporters. Registered supporters were all citizens who were on the Electoral Register with a valid polling number and decided to pay a fee of $£ 25$ to participate as voters in the party leadership selection. Affiliated supporters, in contrast, were members of the trade unions or of socialist societies. If they were already in the party's membership system, they would have been eligible to vote, whereas new affiliates could be recruited within the deadline set in the timetable.

Regarding the de-selection mechanism, according to the Labour Party's rules, when the party is in opposition, the sitting leader may be challenged each year prior to the annual session of the party conference. Any challenger's nomination must be supported by $20 \%$ of the combined House of Commons' MPs and European MPs. In contrast, when the Labour party is in government, the leader's term is indefinite (see also Cross and Blais 2012), and a new election shall proceed only if requested by a majority of the party conference on a card vote. 
Concerning the voting system dimension, the Labour Party's rules provided that the selection must be held under the so-called alternative vote (AV). In this electoral system, also known as instant runoff, the voters rank the candidates in the order they prefer by putting a number next to each candidate, with a 1 for their favourite, 2 for their second favourite, and so on. If no candidate obtains an absolute majority, the candidate with the lowest number of first preferences is eliminated from the count, and his or her ballots are taken into consideration for the other preferences expressed there, starting from the second one. The process is repeated until a candidate reaches more than $50 \%$ of the valid votes. As we shall see in the next section, in 2016 only two candidates ran for the leadership, so the AV electoral system worked as a majority system. In 2015, however, four candidates participated in the race, so the AV system functioned as intended.

In 2016, not only did the Brexit referendum catalyse the push for a possible change in the Labour Party leadership, but it also led to the resignation of the Conservative Prime Minister David Cameron, who had campaigned for Remain. His resignation on 24 June 2016 opened the race for the selection of the next Conservative Party leader. Indeed, a contest for the leadership of the Conservative Party can be triggered in two situations: either $« 15 \%$ of Conservative MPs write to the Chairman of the 1922 Committee $^{1}$ saying they no longer have confidence in the leader of the Conservative Party, or...he or she resigns» (Johnston and Maer 2016, p. 4).

Regarding the rules regulating the competition, let us begin with the candidacy. First, only Members of Parliament can run for the Conservative leadership. A prospective candidate must be formally proposed and seconded by two MPs. Following the Conservative Party Constitution, the 1922 Committee presents to the party «as soon as reasonably practical» a choice of candidates for the selection of leader. It should also be noted that a leader who has resigned cannot participate in the competition.

Passing to the selectorate, theoretically, the Conservative Party's leadership selection is a two-stage process. First, Conservative MPs select two candidates from among those who presented their candidacy. Second,

\footnotetext{
${ }^{1}$ As explained on the UK Parliament's official website (www.parliament.uk), «the 1922 Committee, also known as "the 22", is a committee of all backbench Conservative MPs that meets weekly when the Commons is sitting. Its chair, usually a senior MP, is elected by committee members and has considerable influence within the Parliamentary Party. The 1922 Committee takes its name from a meeting of Conservative MPs in October 1922 which led to the end of the party's coalition government with the Liberals».
} 
through an OMOV system, party members vote for their preferred candidate from this shortlist of two people. Therefore, in the first stage, the selectorate consists of Conservative MPs, whereas in the second stage, it consists of the whole party membership. An add-on is required, however: to be entitled to vote, Conservative Party rules state that members must have joined the party at least three months before the leadership selection. In the case of Theresa May's election to the party leadership, members had to join the party no later than the 9 June 2016.

As for the de-selection mechanism, since 1998, the British Conservative Party has been using the no-confidence vote (Kenig 2009) to de-select its leader. The procedure is as follows: at least $15 \%$ of the Conservative party's parliamentary group must sign a request for a noconfidence vote. The selectorate is composed of Conservative MPs, and the loss of the vote requires the sitting leader's resignation.

If we limited our analysis to the vote of the members (who choose only between two candidates), the description of the Conservative party's voting system would be very simple: the candidate who receives the highest number of votes is elected as party leader. Members vote via a postal or online ballot. It could also be interesting, however, to examine the process that leads to the two-candidate competition. Therefore, having clarified the rules of the 2016 leadership contests both for the Labour and the Conservative parties, in the next section, we investigate the results of these competitions.

\section{Results and participation in the 2016 Labour and Conservative leadership selection}

The competitions for the Labour and Conservative leaderships in 2016 were very different ${ }^{2}$. This diversity is less attributable to differences in the rules of the game - which, as we know, do exist - as to the competition. Briefly, whereas the Labour Party's leader was selected by a large selectorate that included party members and supporters, the Conservative leader was chosen exclusively by the Conservative Party's parliamentary group.

Starting from the Labour contest, as noted by Dorey and Denham (2016), the main issue was not, as in 2015, whether and how Corbyn could

\footnotetext{
${ }^{2}$ More information on past leadership selection races in the most important British parties can be found in Denham and Dorey (2017) and in the online appendices of the book edited by Pilet and Cross (2014), which can be downloaded from the following website: https://www.routledge.com/The-Selection-of-Political-Party-Leaders-in-ContemporaryParliamentary/Pilet-Cross/p/book/9780415704168.
} 
win the contest but by what margin. The 2016 competition for Labour's leadership was initially a three-candidate race among Angela Eagle, Owen Smith, and the incumbent Jeremy Corbyn. A few days after the announcement of her candidacy, however, Angela Eagle decided to strategically exit the competition and endorse Owen Smith.

As shown in Table 1, the selection - held from 22 August 2016 to 21 September 2016 - was clearly won by Corbyn with $61.8 \%$ of valid votes, with $38.2 \%$ for Owen Smith. Before commenting on the electoral results, however, it should be noted that participation was quite high: 507,480 out of 654,006 eligible voters chose to cast their preferences (77.6\%). In 2015, turnout was almost the same, with 422,871 out of the 554,272 eligible voters participating $(76.3 \%)$, but in 2015 , approximately 100,000 fewer eligible voters cast ballots.

TAB. 1 - Results and participation. Labour leadership selection, 2016.

\begin{tabular}{|c|c|c|c|c|c|c|c|c|}
\hline & \multicolumn{2}{|l|}{$\begin{array}{l}\text { Party } \\
\text { members }\end{array}$} & \multicolumn{2}{|c|}{$\begin{array}{l}\text { Affiliated } \\
\text { supporters }\end{array}$} & \multicolumn{2}{|c|}{$\begin{array}{l}\text { Registered } \\
\text { supporters }\end{array}$} & \multicolumn{2}{|l|}{ Total } \\
\hline & Votes & $\%$ & Votes & $\%$ & Votes & $\%$ & Votes & $\%$ \\
\hline Jeremy Corbyn & 168,216 & 59.0 & 60,075 & 60.2 & 84,918 & 69.9 & 313,209 & 61.8 \\
\hline Owen Smith & 116,960 & 41.0 & 39,670 & 39.8 & 36,599 & 30.1 & 193,229 & 38.2 \\
\hline Valid Votes & & & & & & & 506,438 & 100 \\
\hline Invalid Votes & & & & & & & 1,042 & \\
\hline Voters & & & & & & & 507,480 & 77.6 \\
\hline Eligible voters & & & & & & & 654,006 & \\
\hline
\end{tabular}

Source: own elaboration on data from labourlist.org.

Turning to the electoral results and observing the data on the basis of the three groups of selectors who participated in the competition (party members, registered supporters, and affiliated supporters), a clear pattern emerges: Corbyn's electoral support decreases as the proximity of selectors to the party becomes greater. Indeed, Corbyn obtained $59 \%$ of the votes among the party members, $60.2 \%$ of the votes among the affiliated supporters (mostly members of the trade unions), and $69.9 \%$ of those selectors who registered themselves with the party to participate the leadership race. In contrast, the votes for Owen show a diametrically opposite trend. 
It should be added that compared to 2015, Corbyn's profile seemed to be more partisan. Indeed, when he was initially elected to the Labour Party's leadership, Corbyn obtained $83 \%$ of the votes of registered supporters and $49 \%$ of party members' votes. As Dorey and Denham (2016) note, this change in Corbyn's selectorate composition probably depended among other things - on the fact that many of those who voted for Corbyn in 2015 as registered supporters decided to join the Labour Party. This conjecture might be confirmed by the increase in the Labour party's membership (from 245,500 members in the summer of 2015 to 338,000 members one year later). This growth seems to be due to two factors: first, the dragging effect due to Corbyn's victory that certainly pushed a portion of his supporters to join the party; second, the increase in the fee level for registered supporters from $£ 3$ in 2015 to $£ 25$ in 2016 . Confronted with this fee increase, some would-be registered supporters may have decided to obtain full membership.

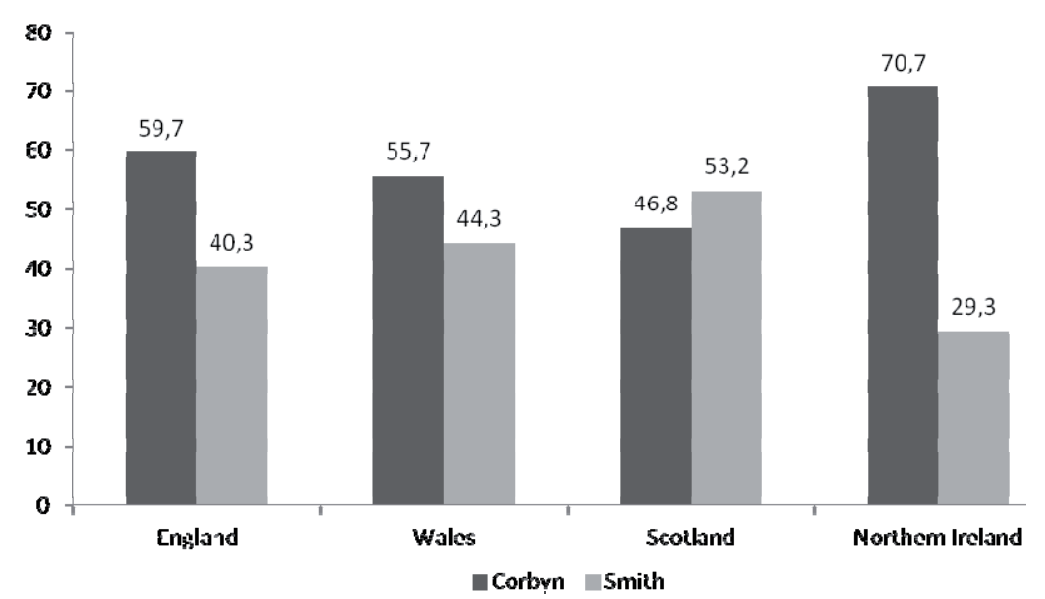

FIG. 1 - Labour leadership competition, 2016 - Electoral results on each UK's nation.

Looking at the territorial distribution of the vote, Corbyn's victory presented some peculiarities. To begin with, Corbyn's electoral performance ranged from the $70.7 \%$ of valid votes obtained in Northern Ireland to the $46.8 \%$ of Scotland, the only nation where the Labour party's leader, in contrast with 2015 , lost the race.

To better comprehend the results of the selection, we must also consider the data from London, where Corbyn gained 53\% of the vote. Some scholars hypothesised a link between the low-profile performance of 
Corbyn in Scotland and London and the results of the Brexit referendum. For instance, Dorey and Denham (2017) argue, «It is, perhaps, significant that both London and Scotland were also strong supporters of Remain in the recent EU referendum, and this might have curbed some support for Corbyn in these two areas». At first glance, this interpretation seems plausible. In fact, during the Brexit referendum, in Scotland and London, the Remain side reached the top-two results in the whole country: $62 \%$ in Scotland and $59.9 \%$ in London. This conjecture should be examined and verified with greater attention since Northern Ireland (where Corbyn scored his best results) was also an area where the Remain side returned an absolute majority of votes. Moreover, Corbyn's victory seems to be even more significant in that he defeated Smith even in Wales, where Smith grew up and where his constituency was located ${ }^{3}$.

Corbyn's victory was large and maybe even predictable, to a certain extent. As we will explain, the victory of Theresa May was very different. Whereas the selection of the leader in Labour's case only implied the selection of the head of the main opposition party, in the Conservatives' case, not only was the position of party leader to be fulfilled but also that of the new Prime Minister after the resignation of David Cameron. This may have been one reason pushing Conservative MPs to nominate the new party leader without leaving room for the party members.

The race for the Conservative Party's leadership was run by five candidates: Stephen Crabb, MP for the district of Preseli Pembrokeshire (Wales) and Secretary of State for Work and Pensions, announced he would stand as a candidate on a ticket with Sajid Javid, Business Minister; Liam Fox, MP for North Somerset (England) since 2010, who had joined the contest for the Conservative Party's leadership in 2005, when he was eliminated after the second ballot among MPs; Michael Gove, MP for Surrey Heath (England) and Secretary of State for Justice, who initially supported the candidacy of Boris Johnson but then announced his own candidacy at the end of June, without informing Johnson; Andrea Leadsom, MP for South Northamptonshire and Minister of State for Energy, who announced her candidacy at the end of June by focusing particularly on a rapid exit of the United Kingdom from the European Union; and finally, Theresa May, MP for Berkshire (England) and Home Secretary in Cameron's Cabinet, who, despite having voted for 'Remain', did not support a second referendum, demonstrating that she would accept the outcome of the Brexit vote.

\footnotetext{
${ }^{3}$ In particular, Owen Smith's constituency is that of Pontypridd.
} 
As Table 2 shows, in the first ballot (5 July 2016), Theresa May obtained the support of half of the MPs (50.2\%), placing herself first. Leadsom came in second place with $20.1 \%$ of the votes. As imposed by the rules, Fox, scoring the lowest result, was eliminated. Crabb then withdrew from the competition, endorsing Theresa May. Even the second ballot ( 7 July 2106) was led by May, who received 199 votes out of $329(60.5 \%)$. Once again, second place went to Leadsom with $25.5 \%$ of the MPs' support. Michael Gove, having obtained only $14 \%$ of the valid votes and being in third and last position, was eliminated from the contest. Theoretically, the floor should have been given to the Conservative party's membership, which, by means of an OMOV system, should have elected the leader of the party and, as a result, the new Prime Minister. Fearing that two months of electoral campaigning (the announcement of the winner would have been made on 9 September 2016) could have destabilised a country already under strong pressure by the Brexit vote, however, Leadsom decided to withdraw from the competition. Theresa May, without going through a party member vote, became the new party leader, and on 13 July 2016, she entered No. 10 Downing Street. To keep the party united, the new PM appointed Leadsom, Fox and Boris Johnson as members of her Cabinet.

TAB. 2 - Results. Conservative leadership selection, 2016.

\begin{tabular}{lllll}
\hline \multirow{2}{*}{ Candidate } & \multicolumn{2}{l}{ First ballot } & \multicolumn{2}{l}{ Second ballot } \\
\cline { 2 - 5 } Theresa May & Votes & $\%$ & Votes & $\%$ \\
\cline { 2 - 5 } Andrea Leadsom & 165 & 50.2 & 199 & 60.5 \\
Michael Gove & 66 & 20.1 & 84 & 25.5 \\
Stephen Crabb & 48 & 14.6 & 46 & 14.0 \\
Liam Fox & 34 & 10.3 & Withdrew \\
\hline Total & 26 & 7.9 & Eliminated \\
\hline Source: & 329 & 100 & 329 & 100 \\
\hline
\end{tabular}

Source: own elaboration on data from en.wikipedia.org.

Note: David Cameron did not take part in the election; as a consequence, there are 329 voters instead of 330 . 


\section{Conclusions}

The growth in the selectorate's inclusiveness in party leader and candidate selection processes has involved a fair number of Western European political parties in the past several decades. This trend, which some have connected to intra-party democracy ${ }^{4}$, can also be interpreted as a process of organisational adaptation by which party elites try to face the weakening of long-term political identities and their ongoing legitimacy crisis (Gauja 2012). In other words, parties have partly changed their organisation by involving their members in an increasingly larger set of political decisions. This is also true concerning the party leader selection rules within the most important British parties.

From this viewpoint, the Labour case seems particularly interesting. Both the procedures and the resulting outcomes in the last two leadership selection processes (2015 and 2016) can also be seen in light of the series of election defeats suffered by the Labour after Tony Blair's resignation and the subsequent rise of Gordon Brown to party leadership in 2007. In 2010, the Labour Party decreased from 35.2\% of the valid votes in 2005 (when they also lost approximately 5 percentage points compared to 2001) to a mere $29 \%$; in 2015 , they obtained only $30.2 \%$ of the valid votes in the general election, thus increasing their share by only a percentage point. In terms of seats, the decline was even more impressive: the party obtained 413 seats in 2001, 355 in 2005, 306 in 2010, and 232 in 2015. In other words, in four elections, the Labour Party lost nearly half its seats in the House of Commons.

These data clearly indicate that the Labour Party needed a renewal. The most immediate solution was thought to be increasing the level of inclusiveness of the selectorate allowed to take part in the selection of the party leader, a decision made in 2014. It remains to be seen whether, from an electoral support viewpoint, Corbyn's Labour Party will be able to achieve the performance of more than a decade ago. For now, a rather uncertain indication comes from the early general election that occurred in June 2017. On the one hand, the Labour Party reached the $40 \%$ of the valid votes, thus regaining approximately 3.5 million votes with respect to the 2015 election; on the other hand, in terms of seats, the growth was less significant, with an increase of just 30 seats compared to 2015.

On the Conservative Party's side, we know that despite the 1998 opening of the party leader selection process, the recently elected leader, Theresa May, was selected exclusively by the parliamentary group because of the withdrawal of her competitor. Following the procedural changes that occurred almost two decades ago, the Conservative Party allowed their

\footnotetext{
${ }^{4}$ For more details on this point, see Cross and Katz (2013).
} 
members (but, unlike the Labour Party in 2015 and 2016, not their own sympathisers) to make a choice concerning party leadership in $2001^{5}$ and $2005^{6}$. Yet, even in 2003, Conservative members were not involved in the process of leader selection, with Michael Howard as the sole candidate for party leadership. In other words, on different occasions, different selectorates were at play in electing the party leader.

The new procedure for party leader selection, adopted by the Conservative Party in 1998, is therefore characterised by specific features: first, a lack of involvement of party sympathisers; second, on two occasions out of four, the persistence of party elite agreement to avoid the involvement of the membership in the final ballot. Nonetheless, it cannot be denied that even the Conservative Party has tried to react to the political and social changes of the last decades by adopting some organisational reforms, more specifically, by modifying the process of leader selection.

The (re)selection of Jeremy Corbyn and Theresa May as leaders of, respectively, the Labour Party and the Conservative Party in 2016 is particularly instructive to obtain a better grasp on the two British parties. On the one hand, Theresa May's selection shows that if (more) inclusive rules can be activated by the party elites, their influence on the outcome of the competition may be non-existent. On the other hand, Corbyn's selection does not seem to confirm the hypothesis according to which «the UK case provides little if any support for the idea that widening the selectorate which is the most obvious development in the years under consideration leads to radically different candidates, contests and results» (Bale and Webb 2014, p. 27). As the election of the radical and (initially) minority candidate Jeremy Corbyn shows, opening the party leader selectorate to include the sympathisers, as decided by the Labour Party in 2014, may have serious consequences for the party leader selection process.

\footnotetext{
${ }^{5}$ When Iain Duncan Smith won over Kenneth Clarke with $60.7 \%$ of the votes.

${ }^{6}$ When David Cameron became party leader by defeating David Davis with $67.6 \%$ of the votes.
} 


\section{References}

ALLERN, E. H. and R. KARLSEN [2014], «Unanimous by acclamation? Party leadership selection in Norway», in Pilet, J., B. and W. P. Cross (eds.), The Selection of Political Party Leaders in Contemporary Parliamentary Democracies, Abingdon, Routledge, pp. 47-61.

Bale, T. and P. WeBB [2014], «The Selection of Party Leaders in the UK», in Pilet, J.B. and Cross, W.P. (eds.), The Selection of Political Party Leaders in Contemporary Parliamentary Democracies, Abingdon, Routledge, pp. 12-29.

BARneA, S. and G. RAHAt [2007], «Reforming Candidate Selection Methods: A Three-Level Approach», in Party Politics, 13, 3, pp. 375-394.

Bernardi, L., G. SAndri, and A. Seddone [2017], «Challenges of political participation and intra-party democracy: Bittersweet symphony from party membership and primary elections in Italy», in Acta Politica, 52, 2, pp. 218-240.

Bueno De Mesquita, B., J.D. Morrow, R.M. Siverson, and A. SMITH [2002], «Political Institutions, Policy Choice and the Survival of Leaders», in British Journal of Political Science, 32, 4, pp. 559-590.

Collins, R. [2014], «Building a One Nation Labour Party - The Collins Review Into Labour Party Reform», Available at: http://action.labour.org.uk/page/-

/Collins_Report_Party_Reform.pdf?source=14_02_06_CollinsReport_Dele gates\&subsource=labour_email\&utm_medium=email\&utm_source=labour UK\&utm_campaign=14_02_06_CollinsReport_Delegates.

Cross, W.P. and A. Blais [2012], Politics at the Centre, Oxford, Oxford University Press.

Cross, W. and Katz, R.S. (eds.) [2013], The Challenges of IntraParty Democracy, Oxford, Oxford University Press.

Curtice, J. and M. Lisi [2015], «The Impact of Leaders in Presidential and Parliamentary Regimes», in Costa Lobo, M. and Curtice, J. 
(eds.), Personality Politics? The Role of Leader Evaluations in Democratic Elections, Oxford, Oxford University Press, pp. 64-86.

Denham, A. [2010], «Hague Rules, Ok? Electing and Ejecting Conservative Leaders», in Representation, 46, 1, pp. 81-89.

Denham, A. [2017], «Choosing party leaders: Anglophone democracies, British parties and the limits of comparative politics», in British Politics, 12, 2, pp. 250-266.

Denham, A. and P. Dorey [2017], «Tales of the unexpected: The selection of British party leaders since 1963», in British Politics, doi:10.1057/s41293-017-0044-x.

DetTerbeck, K. and I. Rohlfing [2014], «Party leader selection in Germany», in Pilet, J., B. and W. P. Cross (eds.), The Selection of Political Party Leaders in Contemporary Parliamentary Democracies, Abingdon, Routledge, pp. 77-92.

Dorey, P. and A. Denham [2016], «Entirely as expected? What the voting data tells us about Corbyn's re-election». Available at: http://blogs.lse.ac.uk/politicsandpolicy/labour-2016-voting-data/.

Gauja, A. [2012], «The 'Push' for Primaries: What Drives Party Organisational Reform in Australia and the United Kingdom?», in Australian Journal of Political Science, 47, 4, pp. 641-658.

Hazan, R.Y. and G. RAHAT [2010], Democracy within Parties: Candidate Selection Methods and Their Political Consequences, Oxford, Oxford University Press.

Johnston, N. and L. MAER [2016], «Leadership Elections: Conservative Party», in Briefing Papers, 01366, House of Commons Library, pp. 1-21.

KATZ, R. S. and P. MAIR [2002], «The Ascendancy of the Party in Public Office: Party Organizational Change in Twentieth-Century Democracies», in Gunther, R., J. Montero, and J. Linz (eds.), Political Parties: Old Concepts and New Challenges, Oxford, Oxford University Press, pp. 113-135. 
KeniG, O. [2009], «Classifying Party Leaders' Selection Methods in Parliamentary Democracies», in Journal of Elections, Public Opinion and Parties, 19, 4, pp. 443-447.

Kenig, O., W. P. Cross, S. Pruysers, and G. Rahat [2015], «Party Primaries: Towards a Definition and Typology», in Representation, 51, 2, pp. 147-160.

KEniG, O., G. RAHAT, and R.Y. HAZAN [2015], «Leadership Selection versus Candidate Selection: Similarities and Differences», in Sandri, G., A. Seddone, and F. Venturino (eds.), Party Primaries in Comparative Perspective, Farnham, Ashgate, pp. 21-39.

LISI, M. and A. FREIRE [2014], "The selection of party leaders in Portugal», in Pilet, J., B. and W. P. Cross (eds.), The Selection of Political Party Leaders in Contemporary Parliamentary Democracies, Abingdon, Routledge, pp. 124-140.

Musella, F. [2018], Political Leaders Beyond Party Politics, Basingstoke, Palgrave Macmillan.

Pilet, J.B. and W.P. Cross (eds.) [2014], The Selection of Political Party Leaders in Contemporary Parliamentary Democracies, Abingdon, Routledge.

Pilet, J. B. and B. WAUTERS [2014], «The selection of party leaders in Belgium», in Pilet, J.B. and W.P. Cross (eds.), The Selection of Political Party Leaders in Contemporary Parliamentary Democracies, Abingdon, Routledge, pp. 30-46.

PoguntKe, T. And P.D. WebB [2005], The Presidentialization of Politics, Oxford, Oxford University Press.

PunNeTt, R.M. [1992], Selecting the Party Leader. Britain in Comparative Perspective, Hemel Hempstead, Harvester Wheatsheaf.

PunNETT, R.M. [1993], «Selecting the party leader in Britain», in European Journal of Political Research, 24, 3, pp. 257-276. 
RAHAT, G. and R.Y. HAZAN [2001], «Candidate selection methods An analytical framework», in Party Politics, 7, 3, pp. 297-322.

Wauters, B. [2015], «Turnout Rates in Closed Party Leadership Primaries: Flash and Fade Out?», in Government and Opposition, 50, 2, pp. 218-239.

WebB, P.D. and T. BALE [2017], «No Place Else To Go: The Labour Party and the Trade Unions in the UK», in Allern, E.H. and T. Bale (eds.), Left-of-Centre Parties and Trade Unions in the Twenty-First Century, Oxford, Oxford University Press, pp. 246-263. 